\title{
CRYPTOSPORIDIUM PARVUM (EUCOCCIDIORIDA: CRYPTOSPORIIDAE) IN CALVES: RESULTS OF A LONGITUDINAL STUDY IN A DAIRY FARM IN SFAX, TUNISIA
}

\author{
SOLTANE R.*, GUYOT K.**, DEI-CAS E.** \& AYADI A.*
}

\section{Summary:}

A longitudinal study was undertaken to determine the prevalence of Cryptosporidium in a dairy farm in Sfax, Tunisia. 480 faecal samples were obtained from 30 calves under one month of age. All faecal samples were analysed for Cryptosporidium oocysts by microscopic examination of smears stained by modified Ziehl Neelsen technique. The parasite was detected in 26 calves $(86.7 \%)$. Infection was significantly associated with diarrhoea. A molecular characterization, performed in seven calves, confirmed that isolates were C. parvum. This work is the first report on Cryptosporidium in calves in Tunisia.

KEY WORDS : Cryptosporidium, Apicomplexa, prevalence, calves, genotyping, Tunisia.

\section{INTRODUCTION}

T The genus Cryptosporidium (Apicomplexa: Eucoccidiorida: Cryptosporiidae) is responsible of gastrointestinal illness in a wide variety of animals including humans (Caccio, 2005; de Graaf et al., 1999; Joachim, 2004). In calves, Cryptosporidium is one of the primary etiologic agents of neonatal calf diarrhoea (Nydam et al., 2001). Though one to three weeks oldcalves seem to be most susceptible, Cryptosporidium spp. has also been found yet in cattle over two years of age (Henriksen \& Krogh, 1985). Dairy calves can excrete high numbers of oocysts for weeks, and there are indications that the disease can potentially reduce the growth performance of ruminants (Ralston et al., 2003) and cause high morbidity and sometimes high mortality rates in calves (Singh et al., 2006; Fayer et al., 1997; Olson et al., 2004a). A number of North American and European studies have shown Cryptospori-

\footnotetext{
* Laboratoire de Parasitologie-Mycologie, Faculté de Médecine, Sfax, Tunisie.

* Institut Pasteur de Lille, Laboratoire Écologie du Parasitisme (EA3609, IFR142) et Service de Parasitologie-Mycologie, Département de Microbiologie, Faculté de Médecine, Centre Hospitalier Régional Universitaire, Lille, France.

Correspondence: Raya Soltane.

Tel : 0021621248198 - Fax : 0021671399789.

E-mail: soltane_raya@yahoo.fr
}

Résumé : CRYPTOSPORIDIUM (APICOMPLEXA: EUCOCCIDIORIDA: CRYPTOSPORIIDAE) CHEZ LES VEAUX : RÉSULTATS D'UNE ÉTUDE LONGITUDinale DANS UNE FERME LAITIÈRe À SFAX, Tunisie

Une étude longitudinale a été réalisée pour déterminer la prévalence de Cryptosporidium dans une ferme laitière à Sfax, Tunisie. 480 échantillons fécaux ont été obtenus à partir de 30 veaux d'âge inférieur à un mois. Tous ces échantillons ont été analysés par examen au microscope des frottis colorés par la technique de Ziehl Neelsen modifiée pour la détection des oocystes de Cryptosporidium. Le parasite a été détecté chez 26 veaux $(86,7 \%)$. L'infection a été significativement associée à la diarrhée. La caractérisation moléculaire, réalisée pour sept veaux, a confirmé que les isolats ont été $C$. parvum. Ce travail est le premier rapport sur Cryptosporidium chez des veaux en Tunisie.

MOTS CLÉS : Cryptosporidium, Apicomplexa, prévalence, veau, génotypage, Tunisie.

dium to be highly prevalent in dairy calves with infection rates as high as $100 \%$ in some herds, and have also demonstrated an association between parasite infection and diarrhoea and significant production losses (de Graaf et al., 1999; O'Handley et al., 1999; Huetink et al., 2001; Olson et al., 2004b). Up to now, no study has been carried out on the prevalence of Cryptosporidium in cattle in Tunisia. In light of the veterinary importance, causation of production losses and its zoonotical potential, more knowledge about the prevalence of the parasite was needed. The objective of the present study was to determine the prevalence of Cryptosporidium in calves in a dairy farm in Tunisia.

\section{MATERIAL AND METHODS}

\section{FAECAL SPECIMENS}

tool specimens were collected in 2000 from one dairy farm localised in the Sfax district (center east of Tunisia). The farm was selected taking into consideration proximity to the university and farmer cooperativeness. Thirty calves were surveyed from the newborn to the one month age. Stools were collected directly from the rectum, daily for the first week, every two days during the second week and every three days during the third and fourth weeks. Sixteen stool spe- 
cimens were, therefore, obtained from each calf (a total of 480 calves stools specimen was examined). A calf was considered infected with Cryptosporidium if oocysts were microscopically observed in at least one stool specimen. The consistency of the stool was recorded as liquid, soft or normal, the two former being considered as diarrhoea. Twenty five samples of soil (including areas where infected calves were reared) were also collected from the farm. The faecal specimens were stored at $4^{\circ} \mathrm{C}$ in a $2.5 \%$ aqueous potassium dichromate solution until examination.

\section{MICROSCOPIC EXAMINATION}

To diagnose the Cryptosporidium presence in calves, a fraction of faecal specimens was concentrated by the conventional Formalin-ether sedimentation technique (Ritchie) (Young et al., 1979). Smears of emulsified faecal pellets were then stained by modified Ziehl Neelsen technique (Henriksen \& Pohlenz, 1981) and screened for Cryptosporidium oocysts by microscopic examination at $1000 \times$ magnification.

\section{STATISTICAL ANALYSIS}

A Chi-square test using a $95 \%$ confidence interval was used to study the relationship between the two variables diarrhoea and Cryptosporidium detection in newborn calves.

\section{MOLECULAR ANALYSIS FOR GENOTYPING}

Cryptosporidium genotyping was done subsequently only for seven isolates of calves. For DNA extraction, oocysts contained in stools were ruptured by using three freeze-thaw cycles (liquid nitrogen, $3 \mathrm{~min}$, and $56^{\circ} \mathrm{C}, 3 \mathrm{~min}$ ) in a lysis buffer (Tris $10 \mathrm{mM}$; EDTA $0.1 \mathrm{mM}$; SDS $1 \%$ ). Proteinase $\mathrm{K}$ was added at a final concentration of $0.2 \mathrm{mg} / \mathrm{ml}$ and an overnight digestion at $55^{\circ} \mathrm{C}$ was performed. DNA was then extracted by using phenol and chloroforme-isoamylic alcohol. DNA was precipitated by ethanol in presence of sodium acetate.
Crude DNA was purified using the DNA Clean Up Kit (Promega, Madison, Wis.). An additional polyvinylpyrrolidone (PVP; Sigma-Aldrich) treatment of the DNA was finally performed to eliminate all polymerase chain reaction (PCR) inhibitors. For molecular identification, a fragment of the $18 \mathrm{~S}$ rRNA gene was amplified by nested PCR using primers reported by Xiao et al. (2001). Amplified products were sequenced by using the BigDye ${ }^{\circledR}$ Terminator v3.1 Cycle Sequencing Kit (Applied Biosystems). In addition to this genotyping technique, DNA amplification and restriction fragment length polymorphism (RFLP) at the Laxer locus were performed as previously reported (Guyot et al., 2002).

The nucleotide sequences generated in this study has been deposited in GenBank under accession number EF158462.

\section{RESULTS}

$\Lambda$ 11 cattle faecal samples $(n=480)$ were collected from 30 young calves bred in the same farm. The Cryptosporidium overall prevalence was $86.7 \%$ (26/30). The oocyst excretion was first detected five days after birth with a prevalence of $10 \%$ (Fig. 1). The percentage of calves infected increased up to $70 \%$ at the age of 13 days and then decreased to reach $10 \%$ at the age of 28 days. The calf's diarrhoea was associated $\left(\mathrm{P}<10^{-7}\right)$ with the Cryptosporidium infection (Table I). 99 (20.6\%) of the samples had faecal scores indicative of diarrhoea. Of these diarrhoeic samples, 55 (55.5 \%) were shedding Cryptosporidium oocysts. In

\begin{tabular}{lccc}
\hline Number of faecal samples & Diarrhoeic & Normal & Total \\
\hline Positive for Cryptosporidium & 55 & 89 & 144 \\
Negative for Cryptosporidium & 44 & 292 & 336 \\
Total & 99 & 381 & 480 \\
\hline
\end{tabular}

Table I. - Cross tabulation of faecal consistency and detection of Cryptosporidium oocysts.

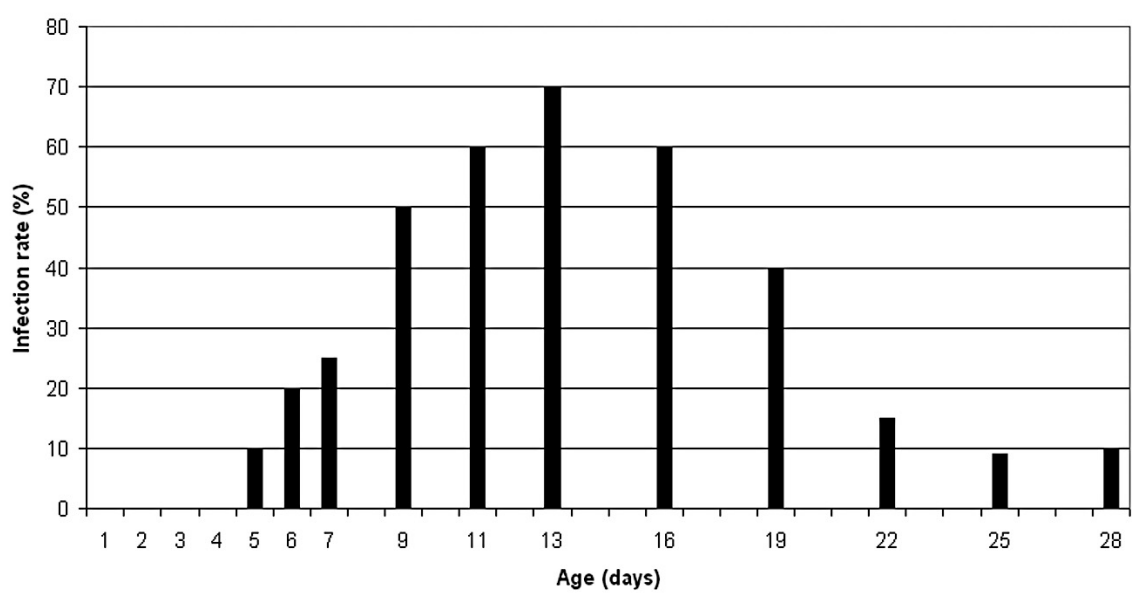

Fig. 1. - Frequency distribution of calves infected with Cryptosporidium by age. 


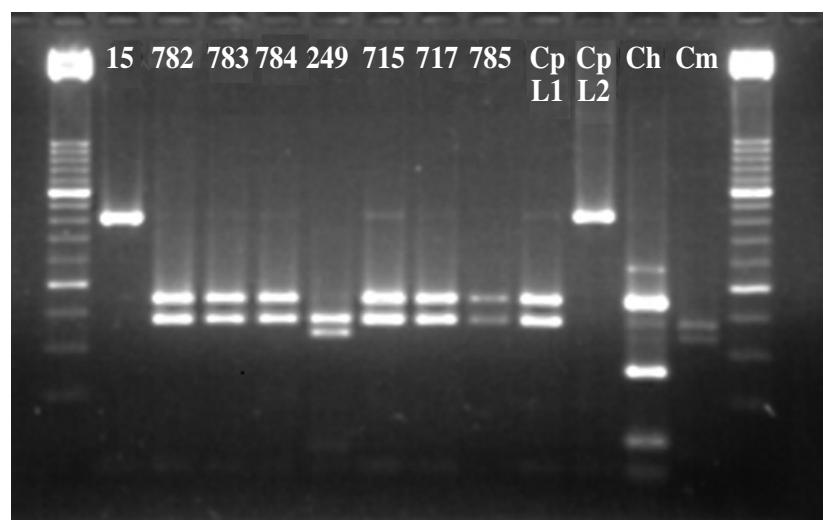

Fig. 2. - Ethidium bromide-stained agarose gel of the Cryptosporidium Laxer fragment after triple digestion with $M w o \mathrm{I}, M l u \mathrm{I}$ and BpmI. Genotyped isolates were six of the seven calf-derived isolates (782, 783, 784, 715, 717, 785) (isolates 15 and 249 were a human and broiler chicken-derived isolates respectively). Isolate controls were C. parvum subgenotype L1 (CpL1), C. parvum subgenotype L2 (CpL2), C. hominis $(\mathrm{Ch})$ and C. meleagridis $(\mathrm{Cm})$. Size markers were DNA molecular weight marker XIII (Roche).

contrast, only $23.3 \%$ of the 381 non-diarrhoeic samples were shedding oocysts.

No oocyst was detected in samples collected from the environment $(n=25)$ including areas where infected calves were reared.

The molecular-based analysis concerned seven Cryptosporidium isolates. DNA was amplified by nested PCR and the resulting fragment of the 18s rRNA gene was sequenced. Sequences were identified as C. parvum. The Cryptosporidium DNA diagnostic fragment characterized by Laxer et al (Guyot et al., 2002; Laxer et al., 1991) was amplified by PCR. For each isolate, a single amplicon was produced. In agreement with the genotyping of the $18 \mathrm{~S}$ rRNA gene, C. parvum was identified in the seven calves. Moreover, all C. parvum were of the L1-subgenotype (Fig. 2).

\section{DISCUSSION}

T he results of this study shows that Cryptosporidium infection occurred in calves in Tunisia, as also found in numerous similar studies in other countries. This is the first known study to estimate the prevalence of Cryptosporidium in calves in a country of North Africa. Since most dairy cattle become infected in the first month of life (Wade et al., 2000; Fayer et al., 1997), our sampling scheme was directed to target this subpopulation, increasing the chances of case detection.

The prevalence of infection in newborn calves (86.7\%) reported in this study may have varied from some of the previous studies for a number of reasons. With the intermittent shedding pattern of the parasite, it is pos- sible that with only one sample that the prevalence may have been somewhat underestimated (Buret et al., 1990; Ralston et al., 2003). Longitudinal studies have demonstrated that following animals over time will affect prevalence rates considerably. For example, in one longitudinal study, the prevalence varied with month of the year and animal age (Huetink et al., 2001). The results of present study are in conformity to O'Handley et al. (1999), who described $100 \%$ cumulative Cryptosporidium infection rates in dairy calves. They examined every-other-day 20 calves on one farm only. In this study, the examined dairy calves were infected from the first week of age. These results are consistent with the data of Fayer et al. (1998) and O'Handley et al. (1999), who found that calves usually became infected with Cryptosporidium between one and four weeks of age. No infection of Cryptosporidium was found until four days after birth, as Kvac et al. reported as well (2006).

Seventy percent of the 13-day-old calves were found infected with Cryptosporidium (Fig. 1). This corresponds to the first peak of cryptosporidiosis in calves that appears before the weaning. Genotyping could have been performed for samples from seven of these calves and C. parvum (bovine genotype) was identified in all cases. These results are in agreement with the work of Santin et al. (2004) in which C. parvum is shown to constitute $85 \%$ of the Cryptosporidium infections in pre-weaned calves during the first peak of cryptosporidiosis but only $1 \%$ of the Cryptosporidium infections in post-weaned calves, during the second peak of infection. Infection with C. paruum in neonatal calves was associated with diarrhoea. In the present study, $55.5 \%$ of diarrheic and $23.3 \%$ non-diarrheic samples were shedding oocysts. Lise et al. (2005) similarly found that $40.6 \%$ calves were shedding C. parvum oocysts at the time of sampling and $50.5 \%$ of diarrheic and $23.5 \%$ non-diarrheic calves were shedding oocysts. In this study, no oocysts were recovered from soil samples, including areas where infected calves were reared. Although Barwick et al. (2003) reported that the environmental contamination of farms with oocysts was insufficient to account for the high levels of infection seen in cattle, contaminated soil is considered to be a sufficient infection source for newly introduced animals. Other studies support the importance of calfto-calf contact in transmission (Xiao et al., 1993; O'Handley et al., 1999; Wade et al., 2000; Becher et al., 2004). The present work is the first report on Cryptosporidium occurrence in calves in Tunisia associating molecular characterization of few parasite isolates. Since C. parvum from cattle can infect humans, further studies with genotyping of human and animal isolates are necessary to evaluate the public health significance and give further insights into the epidemiology of the infection in Tunisia. 


\section{ACKNOWLEDGEMENTS}

Whe authors thank Anthony Pinon and Nausicaa Gantois from Pasteur Institute of Lille for doing statistical analysis and technical assistance in sequencing respectively.

\section{REFERENCES}

Barwick R.S., Mohammed H.O., White M.E \& Bryant R.B. Prevalence of Giardia spp. and Cryptosporidium spp. on dairy farms in southeastern New York state. Preventive Veterinary Medicine, 2003, 59, 1-11.

Becher K.A., Robertson I.D., Fraser D.M., Palmer D.G \& ThOmpson R.C.A. Molecular epidemiology of Giardia and Cryptosporidium infections in dairy calves originating from three sources in western Australia. Veterinary Parasitology, 2004, 123, 1-9.

Buret A., DenHollander N., Wallis P., Befus D \& Olsen M. Zoonotic potential of giardiasis in domestic ruminants. Journal of Infectious Diseases, 1990, 162, 231-237.

CAccio S.M. Molecular epidemiology of human cryptosporidiosis. Parassitologia, 2005, 47, 185-192.

de GraAf D.C., Vanopdenbosch E., Ortega-Mora L.M., Abbassi H \& Peeters J.E. A review of the importance of cryptosporidiosis in farm animals. International Journal for Parasitology, 1999, 29, 1269-1287.

Fayer R., Gasbarre L., Pasquali P., Canals A., Almeria S \& ZarLENGA D. Cryptosporidium parvum infection in bovine neonates: dynamic, clinical, parasitic and immunologic patterns. International Journal for Parasitology, 1998, 28, 49-56.

FAyer R., SPeER C \& Dubey J. The general biology of Cryptosporidium, in: Cryptosporidium and cryptosporidiosis. Fayer R. (ed.), CRC Pr, Boca Raton, 1997, 1-41.

Guyot K., Follet-Dumoulin A., Recourt C., Lelievre E., Cailliez J.C \& DEI-CAS E. PCR-restriction fragment length polymorphism analysis of a diagnostic 452-base-pair DNA fragment discriminates between Cryptosporidium parvum and $C$. meleagridis and between $C$. parvum isolates of human and animal origin. Applied and Environmental Microbiolology, 2002, 68, 2071-2076.

Henriksen S.A \& Pohlenz J.F.L. Staining Cryptosporidia by a modified Ziehl-Neelson Technique. Acta Veterinaria Scandinavica, 1981, 22, 594-596.

Henriksen S.A. \& Krogh H.V. Bovine cryptosporidiosis in Denmark 1. Prevalence, age distribution and seasonal variation. Nordisk Veterinaermedicin, 1985, 37, 34-41.

Huetink R.E.C., van DER Giessen J.W.B., NOORdhuIZEN J.P.T.M \& Ploeger H.W. Epidemiology of Cryptosporidium spp. and Giardia duodenalis on a dairy farm. Veterinary Parasitology, 2001, 102, 53-67.

JOACHIM A. Human cryptosporidiosis: an update with special emphasis on the situation in Europe. Journal of Veterinary Medicine. B, Infectious Diseases and Veterinary Public Health, 2004, 51, 251-259.

Kvac M., Kouba M \& Vitovec J. Age-related and housingdependence of Cryptosporidium infection of calves from dairy and beef herds in South Bohemia, Czech Republic. Veterinary Parasitology, 2006, 137, 202-209.

Laxer M.A., Timblin B.K \& Patel R.J. DNA sequences for the specific detection of Cryptosporidium parvum by the polymerase chain reaction. American Journal of Tropical Medicine and Hygiene, 1991, 45, 688-694.

Lise A.T.W., Brenna D.J., Martin S.W., Knneth E.L \& Andrew S.P. Prevalence of Cryptosporidium parvum infections in southwestern Canada and its association with diarrhea in neonatal dairy calves. The Canadian Veterinary Journal, 2005, 46, 349-351.

Nydam D.V., Wade S.E, SchaAF SL \& Mohammed H.O. Number of Cryptosporidium parvum oocysts or Giardia spp cysts shed by dairy calves after natural infection. American Journal of Veterinary Research, 2001, 62, 1612-1615.

O'Handley R.M., Cocwill C., Mc Allister T.A., Murray J., Jelinski M., Morck D.W \& Olson M.E. Duration of naturally acquired giardiosis and cryptosporidiosis in dairy calves and their association with diarrhea. Journal of the American Veterinary Medical Association, 1999, 214, 391396.

Olson M.E., O’Handley R.M., Ralston B.J., Mc Aluister T.A \& Thompson R.C.A. Update on Cryptosporidium and Giardia infections in cattle. Trends in Parasitology, 2004b, 20, 185191.

Olson M.E., Ralston B.J., O'Handley R., Guselle N.J \& Applebee A.J. What is the clinical and zoonotic significance of cryptosporidiosis in domestic animals and wildlife. In: Thompson R.C.A., Armson A., Ryan U.M., eds. Cryptosporidium: From molecules to disease. Elsevier Sci, $2004 \mathrm{a}$.

Ralston B.J., McAllister T.A \& Olson M.E. Prevalence and infection pattern of naturally acquired giardiasis and cryptosporidiosis in range beef calves and their dams. Veterinary Parasitology, 2003, 114, 113-122.

Santin M., Trout J.M., Xiao L., Zhou L., Greiner E \& Fayer R. Prevalence and age-related variation of Cryptosporidium species and genotypes in dairy calves. Veterinary Parasitology, 2004, 122, 103-117.

Singh B.B., Sharma R., Kumar H., Banga H.S., Aulakh R.S., GILl J.P.S \& Sharma J.K. Prevalence of Cryptosporidium parvum infection in Punjab (India) and its association with diarrhea in neonatal dairy calves. Veterinary Parasitology, 2006, 140, 162-165.

Wade S.E., Mohammed H.O \& SchaAf S.L. Prevalence of Giardia sp., Cryptosporidium parvum and Cryptosporidium muris (C. andersoni) in 109 dairy herds in five countries of southeastern New York. Veterinary Parasitology, 2000, 93, 1-11.

XiaO L., Herd R.P \& Rings D.M. Concurrent infections of Giardia and Cryptosporidium on two ohio farms with calf diarrhea. Veterinary Parasitology, 1993, 51, 41-48.

Young K.H., Bullock S.L., Melvin D.M. \& Spruill C.L. Ethyl acetate as a substitute for diethyl ether in the formalinether sedimentation technique. Journal of Clinical Microbiology, 1979, 10, 852-853.

Reçu le 3 février 2007 Accepté le 17 juillet 2007 